\title{
Prognostic impact of immunophenotyping of diffuse large B-cell lymphoma - a single-centre experience
}

\author{
Sanja Trajkova ${ }^{1}$, Svetlana Krstevska-Balkanov ${ }^{1}$, Gordana Petrusevska ${ }^{2}$, \\ Lidija Cevreska ${ }^{1}$, Aleksandra Pivkova-Veljanovska ${ }^{1}$, Marija Popova-Labacevska ${ }^{1}$, \\ Nevenka Ridova ${ }^{1}$, Simona Stojanovska ${ }^{1}$, Irina Panovska-Stavridis ${ }^{1}$ \\ ${ }^{1}$ University Clinic for Hematology, Faculty of Medicine, Ss. Cyril and Methodius University in Skopje, \\ Mother Theresa 17, 1000 Skopje, Republic of North Macedonia \\ ${ }^{2}$ Institute of Pathology, Faculty of Medicine, Ss. Cyril and Methodius University in Skopje, \\ 50 Divizija 6, 1000 Skopje, Republic of North Macedonia
}

Received: June 2021; Accepted: July 2021

\begin{abstract}
The concept generated by biological expression profile divided patients with diffuse large B-cell lymphoma (DLBCL) into two subtypes. This concept has been presented in the recent editions of WHO classification and became a prognostic tool. Aim of the study was introduction of new three-marker model for immunohistochemical and prognostic subclasification of patients with DLBCL.

Our retrospective study enrolled 200 adult patients with DLBCL diagnosed and treated in the period between January 2013 to January 2021. They were all treated with chemoimmunotherapy with R+/-CHOP regimen and the median follow-up of the patients was 48 months. We analysed the biopsy samples immunohistochemically with the markers of germinal (BCL6) and post-germinal centre (MUM1), and the marker of apoptosis (BCL2).

Using the immunohistochemical three-marker model, which consisted of BCL-2, BCL-6, and MUM1, we distributed the patients with DLBCL into 2 subgroups: germinal centre - like (GCL) and activated centre-like lymphoma (ACL). The GCL and ACL patients were comparable regarding age, gender and all other already established prognostic parameters. Patients with GCL had overall survival of 140 months, and patients with ACL had overall survival of 88 months. ACL patients with BCL2 expression had a shorter survival compared to ACL patients without BCL2 expression. The difference in survival was statistically significant for $\mathrm{p}=0.01914$.

The study introduced the new three-marker model for immunohistochemical subclasification of patients with DLBCL treated with immunochemotherapy. Apoptotic marker BCL2 is a strong survival predictor. In the present study, we confirmed the prognostic importance of BCL2 protein expression, which showed a predictive capacity in ACL.
\end{abstract}

Keywords: DLBCL, three - marker model, immunohistochemical, BCL2

\section{Introduction}

Non-Hodgkin lymphomas (NHL) are malignant lymphoproliferative diseases, which derivate from $\mathrm{B}$ or $\mathrm{T}$ cells of the immune system, rare natural killer (NK) cells. The classification of the malignant lymphomas had undergone significant reappraisal over the past 50 years. The new WHO classification has been a major breakthrough, particularly the subdivision of diffuse large B-cell lymphoma (DLBCL) into two subtypes: activated B cell type (ACL) versus germinal centre derivate type (GCL) (Swerdlow et al., 2017). DLBCL prognosis is based on clinical parameters (age, performance, LDH

\footnotetext{
* sanjatrajkovamd@yahoo.com
} 
level, stage of disease, number of extra-nodal sites) which are part of International Prognostic Index (IPI) score (Armitage et al., 2017). Younger and older patients have different outcome, and IPI-age adjusted score (Patients <60) (stage of disease, LDH level, performance) was proposed. However, since IPI is not able to identify patients with $50 \%$ less chance for survival, a new predictor model based on immunohistochemistry and IPI independent was applied. Molecular pathogenesis of DLBCL suggests that NHL is a heterogeneous group of diseases deriving from mature B cells ( $85 \%$ of cases) and in minority of cases from $\mathrm{T}$ cells. DLBCL arises from germinal center (GC) or post-GC B cells (activated B cells) since they have undergone hypermutation of the immunoglobulin variable region $(\mathrm{IgV})$ genes, a phenomenon restricted to GC B cells. DLBCL has genetic abnormalities, many of which appear to occur during the gene rearrangements and mutations that characterize normal B cell differentiation, resulting in onset of neoplastic clone.

Immunophenotype profile of DLBCL has been introduced with several markers like: BCL6, CD10, MUM1, CD 138. They have been shown to be differently expressed in the germinal centre B cell-like and activated $B$ cell-like. Stage-specific markers of germinal centre (GC) are: BCL6, CD10 and post-GC differentiation respectively, BCL2, MUM1, VS38c, CD138.

MUM1 expression is detected by immunohistochemistry in a small percentage of BCL6 negative GC B cells in the apical light zone as well as in plasma cells and some activated $\mathrm{T}$ cells. The staining is nuclear, sometimes with associated cytoplasmic positivity (Falini et al., 2000) In DLBCL, MUM1 has been detected in $50-75 \%$ of the cases, either with or without BCL6 expression (Falini et al., 2000). MUM1 expression in DLBCLs may reflect derivation from B cells at a late GC or post GC stage of differentiation, up to a plasma cell. In one microarray study expression of MUM1, in a least $30 \%$ of tumour cells was associated with a significantly worse outcome (Hans et al., 2004). BCL2 gene was found in 20$30 \%$ of DLBCL (Muris et al., 2006). The BCL2 protein located in the mitochondrial inner membrane functions as an anti- apoptotic protein protecting cells from programmed cell death (Danial et al., 2004). BCL2 protein expression has been found in $30-60 \%$ of cases more frequently in nodal than in extranodal tumours. BCL2 protein overexpression in DLBCL has been detected in about $30 \%$ of the cases, usually in the absence of BCL2 gene translocation (Rantanem et al., 2001). There is no evidence to suggest that the presence of a BCL2 translocation at diagnosis has any impact on the survival of patients with DLBCL. In contrast, the prognostic impact of BCL2 protein expression is significant (Colomo et al., 2003; Roh et al., 2020). BCL2 expression in DLBCL ( $>50 \%$ positive tumour cells) is associated with an adverse prognosis. BCL6 protein, a zinc-finger protein which functions as a sequence-specific transcriptional repressor, is selectively expressed by GCB cells in normal lymphoid tissues. BCL6 represses genes involved in lymphocyte activation and differentiation, in cell cycles control and inflammation (Dent et al., 2002). Expression of BCL6 has been found in the majority of DLBCLs, ranging from $57 \%$ to $100 \%$ in various series, including both nodal and extranodal sites (Braaten et al., 2003; Colomo et al., 2003). The biological significance of BCL6 expression in DLBCL is difficult to be determined. While it may reflect a GC stage of differentiation, BCL6 expression may be deregulated by translocation present in about $40 \%$ of the cases and by mutations in its 5 nontranslated regulatory region (detected in $50-80 \%$ of the cases) (Pasqualucci et al., 2003). No consistent correlation has been drawn between $\mathrm{BCl} 6$ gene alterations and protein expression in lymphoma specimens. It is found that high BCL6 expression (assessed at the mRNA level by quantitative RT-PCR or at the protein level by immunohistochemistry) is a strong predictor of increased survival independent of IPI. These findings were not confirmed by Colomo et al. (2003). It has also been suggested that the biological consequences of BCL6 expression in DLBCL might vary according to the presence/absence and the nature of the underlying alteration of the BCL6 gene. The physiological bases of the relationship between improved survival and increased BCL6 expression may be an increased sensitivity to apoptosis of cells overexpressing BCL6 (Artiga et al., 2002). Rosenwald and Standt, the pioneers of genetics expression, have shown that DLBCL could be divided into important subgroups (Rosenwald et al., 2002). Using cDNA microarrays, it has been shown that DLBCL could be divided into 2 important subgroups, regard to prognosis, with GCL, ACL or type 3 (a group of unclassified cases). Where the germinal centre B-cell like group show a significant better survival compared to the activated B cell-like or type 3 groups. The new technique, -cDNA microarray, uses oligonucleotides that are very expensive, and hence, immunohistochemistrye was used for subdividing DLBCL (Wright et al., 2003). There is a distinctive expression of certain markers related to cellular origin that allows differentiation of patients into appropriate prognostic groups (Zinzani et al., 2005). Clinically based IPI has not been proved effective in stratifying patients with DLBCL for therapeutic trials (Dent et al., 2002). Prognostic GCL has presented with a significantly greater likelihood of survival after chemotherapy than ACL (Rosenwald et al., 2002). The starting point of our study was to determine whether immunohistochemical differentiation of patients with DLBCL in the era of modern therapy would enable prognosis based on cellular origin.

\section{Materials and methods \\ Patients and study design}

This was a retrospective study comprising 200 adult 
patients with DLBCL in the period from January 2013 to January 2021. The median follow-up of the surviving patients was 12-96 months (average period of observation was 48 months). The study was realized at the University Clinic for Hematology, Faculty of Medicine, Ss. Cyril and Methodius University, Skopje, Republic of North Macedonia in collaboration with the Institute of Pathology, Faculty of Medicine, Ss. Cyril and Methodius University, Skopje, Republic of North Macedonia.

A medical documentation of a total of 200 adult patients was reviewed. Patients were eligible for the study if they had untreated DLBCL, and each of the patients received an anthracycline-based chemotherapy regimen+/- anti CD20 monoclonal antibody Rituximab.

\section{Inclusion criteria}

Patients aged over 18 years were eligible if they had untreated DLBCL, diagnosed according to the World Health Organization classification with performance status $<2$ (WHO) and cardiac function $(\mathrm{EF}>50 \%)$. Patients were included in the study if tumour samples were $\mathrm{CD} 20+$ according to immunohistochemically staining.

\section{Exclusion criteria}

Patients were excluded from the study if they were HIV positive, had CNS involvement at presentation, or were diagnosed with lymphoproliferative disease after autologous transplantation and transformed lymphoma. Patients with history of malignancy or clinically significant other diseases like: active opportunistic infections, congestive heart failure, symptomatic coronary artery disease, cardiac arrhythmias, myocardial infarction within the last 6 months, abnormal renal and liver function, and uncontrolled diabetes mellitus were excluded from the study, too. Breastfeeding or pregnant women were not included in the study.

A written informed consent was obtained from all patients (Declaration of Helsinki). All data was provided from the medical documentation of the University Clinic for Hematology, Faculty of Medicine, Ss. Cyril and Methodius University, Skopje, Republic of North Macedonia.

\section{Immunohistochemistry}

Immunohistochemical analysis was done at the Institute of Pathology, Faculty of Medicine, Ss. Cyril and Methodius University, Skopje, Republic of North Macedonia.

For histopathology analysis, lymph nodes and extralymph nodes were used. Tissue preparation consisted of: formalin-fixed paraffin sections $4-6 \mu \mathrm{m}$ thick deparaffinised and rehydrated, subsequently coloured with haematoxylin, eosin, Gimsa, PAS and reticulin Gomori. Antibodies required antigen retrieval in citrate buffer for 15 minutes. For immunohistochemistry a standard highly sensitive horseradish peroxidase system in 3 steps was used: Mouse monoclonal antibody was used: Pan B cell markers: Anti Human CD20Cy, B cell, Clone L26; Anti Human CD79a, B cell, Clone JCB117; Anti Human Pan T cell markers: Anti Human CD3, T Cell, Clone F7. 2.38; Anti Human CD43, T Cell, Clone DF-T1. Markers with diagnostic and prognostic value were used: Anti Human BCL2 protein, Clone 124; Anti Human BCL6 protein, Clone PG-B6p; Anti Human CD10, Clone 56C6; Anti Human CD30, Clone Ber-H2; Anti Human CD138, Clone 5F7; Anti Human MUM1, Clone MUM1p; Anti Human IRF4. Sections of reactive tonsil were used as positive controls and normal goat and mouse tissue were used as negative controls.

The proportion of positively stained tumour cells was visually estimated by one pathologist. For each case, the hot-spot with the highest percentage of tumour cells was used for analyses.

All staining was analysed without clinical information. The intensity of staining was also evaluated, but was not used to determine positivity because the variability in tissue fixation and processing appeared to affect the intensity of staining. Cases were considered positive if $30 \%$ or more of the tumour cells were stained with an antibody. BCL2, BCL6 signal were estimated like nuclear or/and cytoplasmatic one. Expression of BCL2, BCL6 had a diagnostic and prognostic value. According to immunophenotype results for BCL-2, BCL-6, and MUM1 were used to subclassify the cases into 2 subtypes: DLBCL with GC and AC phenotype.

\section{Evaluation of patients during the therapy and assessment of response}

Overall survival (OS) was calculated as the time from diagnosis to the date of death or last contact. Patients who were alive at last contact were treated as censored for OS analysis. The survival curve was calculated as a stable percentage of patients for two or more years after therapy.

\section{Statistical analysis}

All results were processed with the statistical program SPSS18 software program, and the results were presented graphically and in tabular form. Methods of descriptive statistics were used, as well as non-parametric and parametric statistical analyzes. Percentage and structure were determined for series with attributive features. Significance of differences in the attribute series was determined using the two-tailed t test and the MannWhiteney test.

In series with numerical features, data distribution with average, standard deviation, minimum and maximum value was tested. The relationship between two occurrences with numerical features was determined by Pearson correlation coefficient ( $r$ ). Differences between two independent samples with numerical characters were determined by t-test for independent samples. Differences 
between two independent samples with attributive traits were determined by the Wilcoxon test. Linear regression analysis and the Cox model were used to determine the relationship between different groups of DLBCL patients like predictors of therapy outcome. The log-rank test (Kaplan Meier method) was used to determine the significance of the difference in survival between the two groups of patients. Levels of probability of achieving the null hypothesis, according to international standards for biomedical sciences, are 0.01 and 0.05 .

\section{Results}

In this retrospective study, we studied medical documentation of 200 adult patients with NH -DLBCL treated at the University Clinic for Hematology, Faculty of Medicine, Ss. Cyril and Methodius University, Skopje, Republic of North Macedonia during January 2013 until 2021 with a period of observation of 12-96 months (median time of observation 48 months). The study was realized at the University Clinic for Hematology, Faculty of Medicine, Ss. Cyril and Methodius University, Skopje, Republic of North Macedonia and Institute of Pathology, Faculty of Medicine, Ss. Cyril and Methodius University, Skopje, Republic of North Macedonia.

Using a three-marker model, a total of 200 patients with DLBCL were distributed in two groups: group 1: 107 patients $(53.5 \%)$ with germinal centre phenotype (CD10+/BCL6+/or BCL6+/MIM1+ and BCL2-/CD30-); group 2: 93 patients $(46.5 \%)$ with non-germinal centre phenotype (BCL2+/CD10-/BCL6- and CD30+or MUM1+). The three-marker model is shown in Fig. 1.

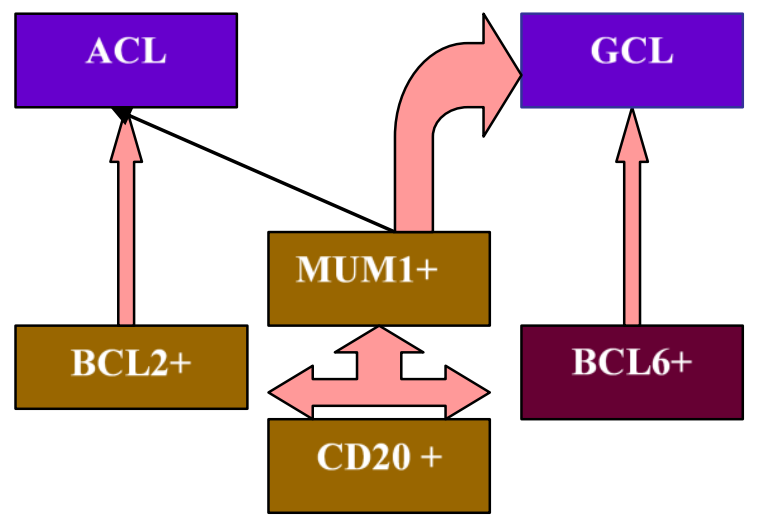

Fig. 1. Three-marker model based on BCL2, BCL6 and MUM1 expression of lymphoma cells.

All cases were considered to be non-germinal centre phenotype (ACL) if both BCL2 and MUM1 were positive and all cases were considered to be germinal centre phenotype (GCL) if BCL6 were positive; cells from the apical light zone of GC which were MUM1 positive were considered to be GCL. Clinical and laboratory features of patients with GCL, ACL are presented in Tables 1 and 2.

Table 1. Clinical features of patients with GCL and ACL

\begin{tabular}{cc}
\hline Clinical features & Percentage of patients $(\%)$ \\
\hline Peripheral lymphadenopathy & 55.7 \\
axillar & 52.9 \\
inguinal & 24.3 \\
abdominal & 24.3 \\
hilar+/-mediastinal & 31.4 \\
splenomegaly & 14.3 \\
hepatomegaly & 17.1 \\
lymphoma bone marrow & 24.3 \\
involvement & 24.3 \\
\hline
\end{tabular}

Tables 3 and 4 present immunohistochemically expression profile of BCL2, BCL6, MUM1, in patients with GCL and ACL according to therapy.

Cumulative proportion surviving in patients with DLBCL and two groups, GCL and ACL, are presented in Fig. 2.

According to Kaplan Meier cumulative proportion surviving, $86 \%$ of patients with GCL had overall survival of 20 months, and $70 \%$ of patients with ACL had overall survival of 20 months. First 55 months were critical for patients with GCL, and first 20 months were critical for patients with ACL (Fig. 2a, 2b). Patients with GCL had overall survival of 140 months, and patients with ACL had overall survival of 88 months (Fig. 2c). The difference in overall survival between the two groups of patients was statistically insignificant ( Log Rank test1.25169 and $p=0.21068$ )

Influences of BCL2 expression on survival of patients with GCL and ACL are shown in Fig. 3.

Log-Rank tests for influences of BCL2, BCL6, MUM1 expression on survival of patients with GCL and ACL are shown in Table 5.

We did not find a difference in the overall survival between the GCL patients with and without BCL2 expression (Log Rank test-1.086673 and $p=0.27718$ ) (Tab.5). According to Kaplan Meier cumulative proportion surviving, $71 \%$ of GCL patients without expression of BCL2 had survival of 50 months, and $100 \%$ of GCL patients with expression of BCL2 had survival of 50 months (Fig. 3a).

BCL2 expression was associated with a statistically significant difference in the overall survival of ACL patients (Log Rank test-2.342817and $p=0.01914$ ) (Tab.5). 
Table 2. Laboratory features of patients with GCL and ACL

\begin{tabular}{cccccc}
\hline \multicolumn{5}{c}{ GCL } \\
\hline Parameter & $\begin{array}{c}\text { Number of } \\
\text { patients }\end{array}$ & average & minimum & maximum & $\begin{array}{c} \pm \text { standard } \\
\text { deviation }\end{array}$ \\
\hline hemoglobin & 107 & 125.8378 & 74.0 & 169.0 & 20.9026 \\
ESR/1 hour & 107 & 39.1351 & 2.0 & 100.0 & 30.5270 \\
LDH & 107 & 456.9189 & 118.0 & 2128.0 & 411.0559 \\
total protein & 107 & 70.5405 & 59.0 & 82.0 & 6.3228 \\
albumen & 107 & 39.8919 & 30.0 & 53.0 & 5.9758 \\
\hline hemoglobin & 93 & 118.0909 & 76.0 & 169.0 & 22.6817 \\
ESR/1hour & 93 & 43.4848 & 6.0 & 130.0 & 35.2155 \\
LDH & 93 & 794.7576 & 136.0 & 2250.0 & 630.7730 \\
total protein & 93 & 68.8182 & 40.0 & 91.0 & 11.5771 \\
albumen & 93 & 36.1212 & 20.0 & 50.0 & 7.4990 \\
\hline
\end{tabular}

According to Kaplan Meier cumulative proportion surviving, $100 \%$ of ACL patients without expression of BCL2 had survival of 20 months, and 59\% of ACL patients with expression of BCL2 had survival of 20 months (Fig. 3b).

Influences of BCL6 expression on survival of patients with GCL and ACL are presented in Fig. 4. We did not find a significant association between BCL6 expression and the overall survival of GCL and ACL patients.

According to Kaplan Meier cumulative proportion surviving, $74 \%$ of GCL patients with expression of BCL6 had survival of 50 months (Fig. 4b) (Log Rank test-
0.478063 and $p=0.63261$ ) (Tab.5); 20-month survival in $63 \%$ of ACL with BCL6 expression and 64\% ACL patients without expression of BCL6 (Fig. 4a).

MUM1 expression did not influence the survival of patients with GCL (Log Rank test-0.608811 and $p=0.54265$ ) and ACL (Log Rank test-0.133586 and $p=0.89373)$

(Fig. 5, Tab. 5); 50-month survival in $74 \%$ and $75 \%$ of GCL patients with and without expression of MUM1, respectively (Fig. 5b); and 20-month overall survival in $70 \%$ vs. $69 \%$ ACL patients with and without MUM1 expression (Fig. 5a, Tab.5).

Table 3. Distribution of immunohistochemical expression profile of BCL2, BCL6, MUM1 in patients with GCL according to therapy

\begin{tabular}{cccc}
\hline \hline Markers & $\begin{array}{c}\text { Imunohistochemical } \\
\text { profile }\end{array}$ & $\begin{array}{c}\text { CHOP } \\
\text { Percentage of patients (\%) }\end{array}$ & $\begin{array}{c}\text { RCHOP } \\
\text { Percentage of patients (\%) }\end{array}$ \\
\hline BCL2 & negative & 45.9 & 54.1 \\
& positive & 0 & 0 \\
BCL6 & negative & 2.7 & 0 \\
& positive & 43.2 & 54.1 \\
MUM1 & negative & 16.2 & 16.2 \\
& positive & 29.7 & 37.8 \\
\hline
\end{tabular}


Table 4. Distribution of immunohistochemical expression profile of BCL2, BCL6, MUM1 in patients with ACL according to therapy

\begin{tabular}{cccc}
\hline \hline markers & $\begin{array}{c}\text { Imunohistochemical } \\
\text { profile }\end{array}$ & $\begin{array}{c}\text { CHOP } \\
\text { Percentage of patients }(\%)\end{array}$ & $\begin{array}{c}\text { RCHOP } \\
\text { Percentage of patients }(\%)\end{array}$ \\
\hline BCL2 & negative & 6.1 & 24.2 \\
& positive & 21.2 & 48.5 \\
BCL6 & negative & 24.2 & 63.6 \\
& positive & 3,0 & 9.1 \\
MUM1 & negative & 9.1 & 63.6 \\
& positive & 18.2 & 37.8 \\
\hline
\end{tabular}

\section{Discussion}

Biological prognostic markers such as BCL2, BCL6, MUM1 (expression associated with inferior survival) and BCL6, MUM1 (expression associated with superior survival) have been analyzed in an effort to improve the subdivision of the DLBCL to germinal center group and non-germinal center group (i.e., activated B-cell like). Also, these markers are named IPI- independent prognostic markers. DLBCL is very heterogeneous on molecular and clinical level, which makes prognostication and decision in treatment strategy difficult. The subdivision of DLBCL according to their mRNA expression profiles is excellent beginning for a new concept-new prognostic model. Since it was very difficult to implement the gene expression and the new technique cDNA microarrays, oligonucleotides that are very expensive, immunohistochemistry is used for subdividing DLBCL profiles. This approach was used in accordance with that presented in the study of Hans et al. (2004). They revealed that conventional immunohistochemistry could give similar results concerning prognosis by using protein expression patterns for selected markers, that is, CD10, BCL6 and MUM1. Using this three-marker model the initial results obtained by microarray analyses could be reproduced in 71 and $88 \%$ of the germinal center B-cell like and non-germinal center B-cell (i.e., activated B-cell like). In our study patients were considered as positive for BCL2, BCL6, MUM1 if $30 \%$ or more of tumor cells were positively stained by the respective antibodies. This is in agreement with the study of Hans et al. (2004), which used this three-marker model and showed that the two subgroups of DLBCL with different origin had different 5year survival prognosis. Five-year survival was reached by using immunohistochemical expression of CD10, BCL6, and MUM1 (Muris et al., 2006). Overall survival (OS) was $76 \%$ for GCL and 34\% for ACL (Hans et al., 2004). The prognostic favourable GCL derivate from germinal cell, have decreased activity of the nuclear factor $\mathrm{kb}$ signalling pathway which, in principle, could block the apoptosis induced by chemotherapy and thus account for relatively poor outcome in ACL (Perona and SánchezPérez, 2004). GCL had a complete remission (CR) of $89 \%$ with 91\% 42-months OS, and ACL had 53\% CR and 38\% 42-months OS (Zinzani et al., 2005). The significant difference in survival may be due to different origin, different cell stage (germinal center stage/post germinal center stage) or to constitutive activation of nuclear factor $\mathrm{kb}$ signalling pathway (Iqbal et al., 2006). A significantly better OS was associated with a group of lymphomas with GCL-like profile and this association was valid even in cases with a low clinical risk factor (IPI of <3) (Swerdlow et al., 2016). One study analysed the influence of BCL2 protein expression (Artiga et al., 2002) found in $20 \%$ of cases. There was an evidence suggesting that the presence of BCL2 protein expression had some impact on the overall survival of patients with ACL, but none on the overall survival of patients with GCL. This is in agreement with our findings. In the GCL group according to BCL2 (positive and negative values) it was registered that $71 \%$ of the patients with negative values survive 50 months and $100 \%$ of the patients with positive BCL2 survive 50 months. In the ACL group according to BCL2 (positive and negative values), were registered that $100 \%$ of patients with negative BCL2 survive for 20 months, and $59 \%$ of patients with positive BCL2 survive for 20 months, a finding that is statistically significant with $p=0.01914$. The $\mathrm{t}(14 ; 18)$ (q32; q21) chromosome translocation is often found in GCL patients, and it is associated with high BCL2 protein expression. Presence of $\mathrm{t}(14 ; 18)$ (q32; q21) chromosome translocation has not been found in patients with ACL, but there was amplification of the BCL2 locus in 18q21. This alternative mechanism $18 \mathrm{q} 21$, or constitutive activation of nuclear factor $\mathrm{kb}$ signalling pathway caused BCL2 protein overexpression in patients with ACL (Artiga et al., 2002; Ochs and Bagg, 2012). BCL2 protein overexpression had different mechanisms in patients with GCL and ACL (Iqbal et al., 2006). BCL2 protein overexpression has prognostic influence in patients with ACL, but not in patients with GCL. The constitutive overexpression of 
Survival Function

- Complete + Censored

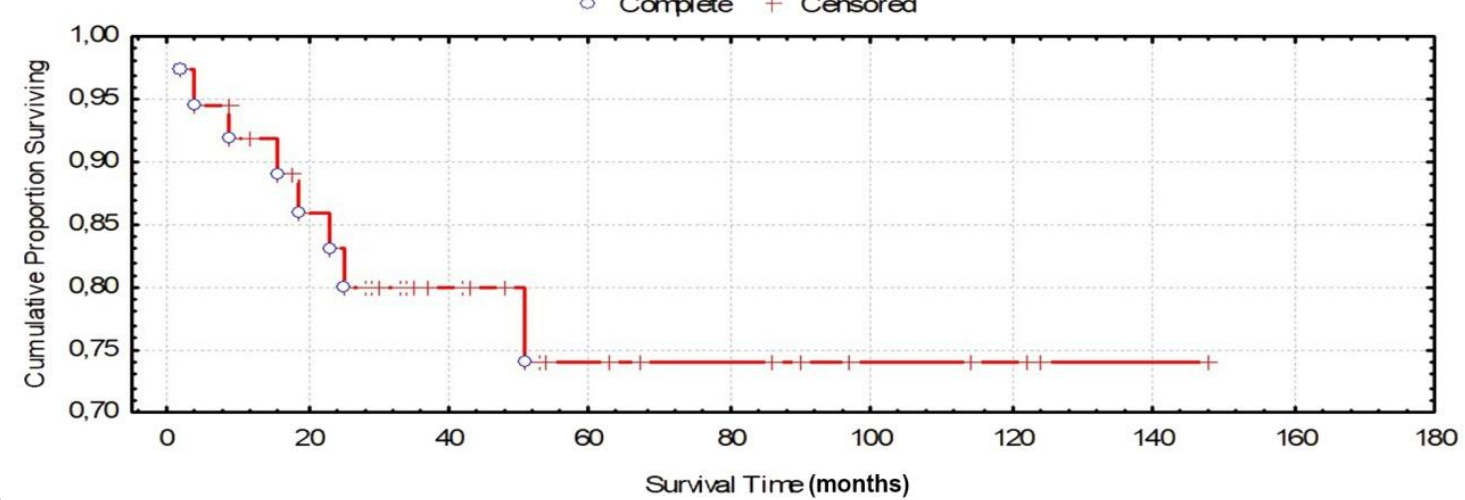

a)

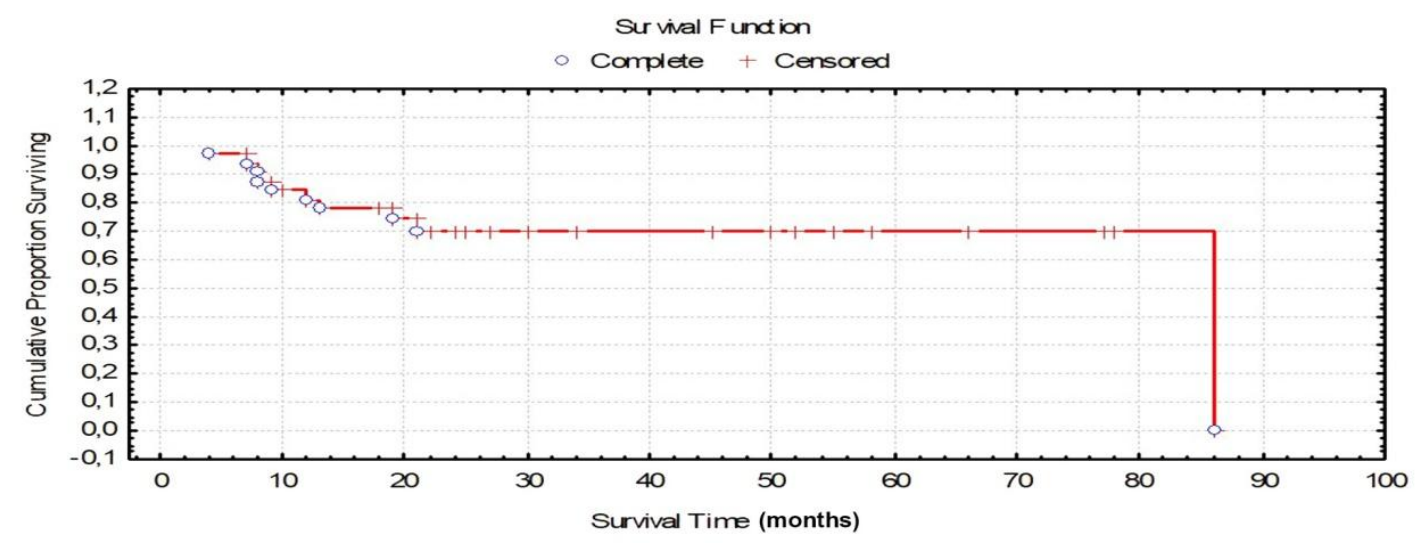

b)

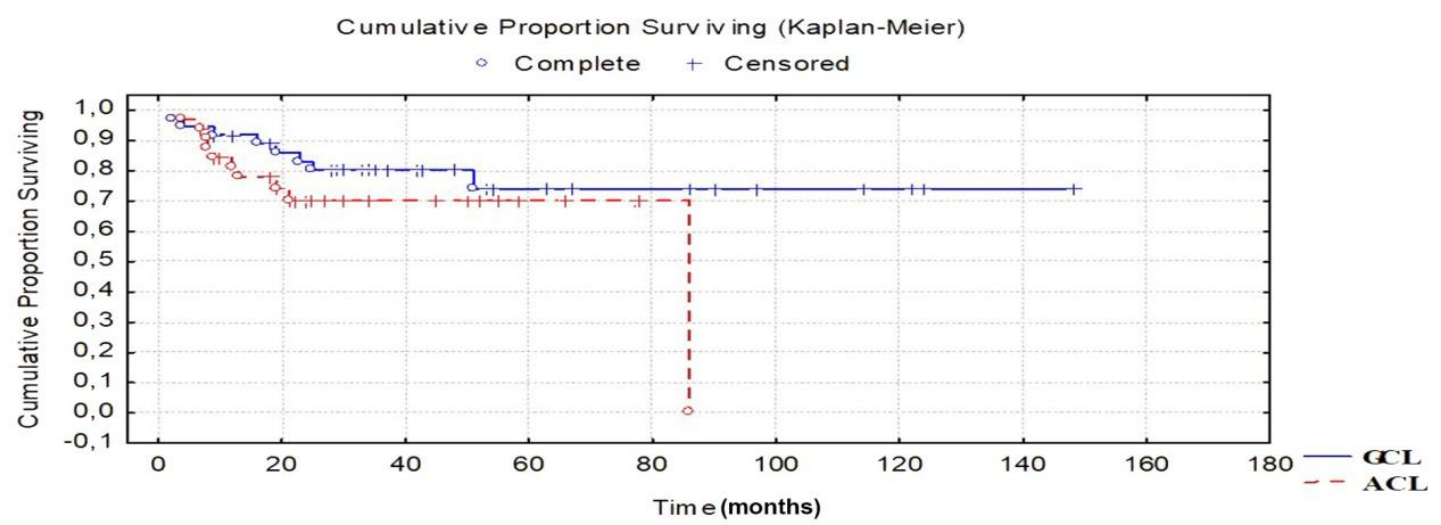

c)

Fig. 2. Overall survival in patients with a) GCL, b) ACL and c) ACL and GCL. 


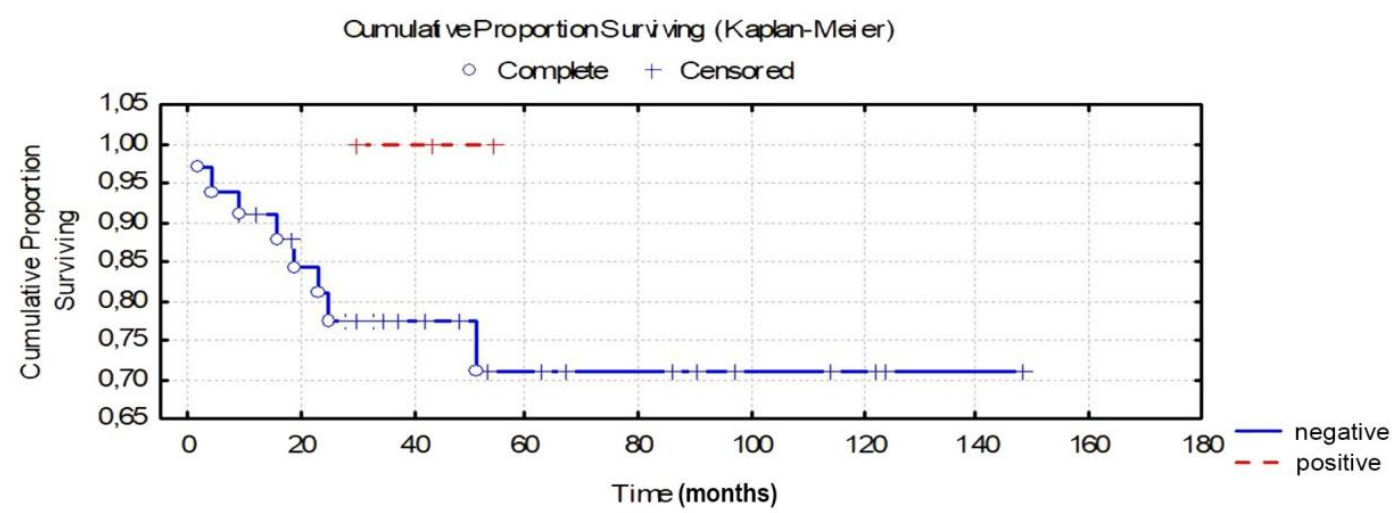

a)

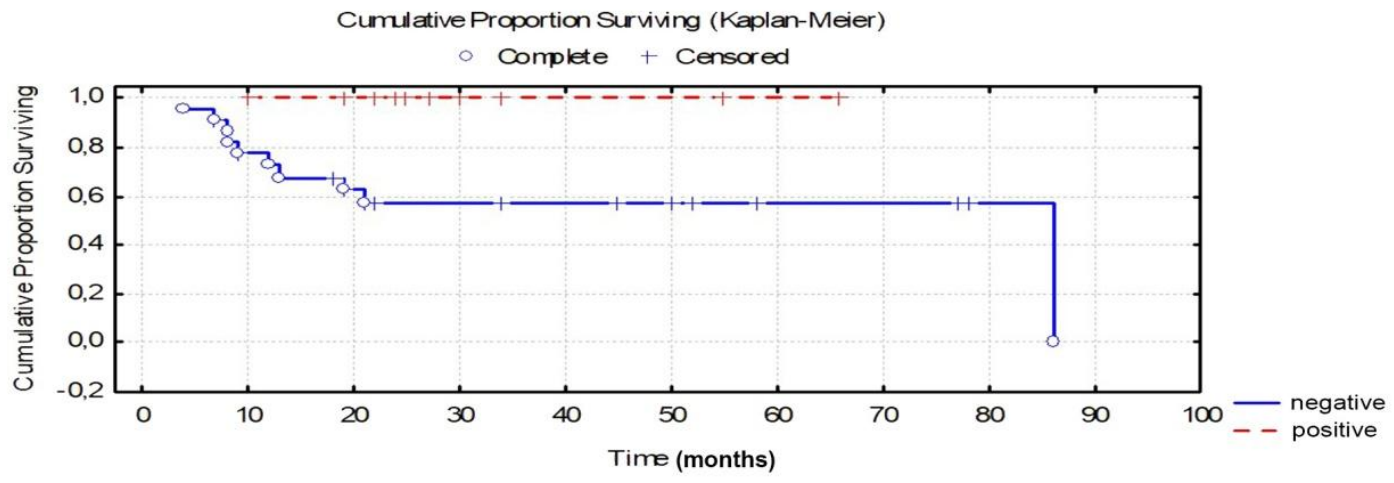

b)

Fig. 3. Overall survival according to BCL2 expression in patients with a) GCL, b) ACL.

Table 5. Log-Rank test for influences of BCL2, BCL6, MUM1 expression on survival of patients with GCL and ACL

\begin{tabular}{lccc}
\hline \hline Statistical analysis & \multicolumn{3}{c}{ Log rank test; p-value } \\
\cline { 3 - 4 } Imunophenotype marker & BCL2 & BCL6 & MUM \\
\hline Type of lymphoma & $2.342817 ; 0.01914$ & $0.2007415 ; 0.84090$ & $0.133586 ; 0.89373$ \\
ACL & $1.086673 ; 0.27718$ & $0.478063 ; 0.63261$ & $0.608811 ; 0.54265$ \\
GCL & &
\end{tabular}

BCL2 in germinal center B cells is inferred by the $\mathrm{t}(14$; 18) (q32; q21) with different mechanism of expression. Different genetic mechanisms result in different clinical expressions. Although BCL2 may act as an antiapoptotic factor, in the $\mathrm{ABC}$ subgroup, it may also serve as a marker for events that are responsible for poor prognosis (eg, NF$\mathrm{kB}$ activation or 18q21 amplification). In the GCB subgroup, BCL2 expression is mainly a result of the $t$ $(14 ; 18)$, thus representing a completely different mechanism of expression. BCL2 protein expression may reflect activation of different genetic pathways in the two subgroups of DLBCL and, therefore, has distinct clinical implications. Nuclear factor kb signalling pathway is an attractive therapy target. A new approach is to use small molecules to target intracellular pathways that have a role in tumour cell survival and growth. Such example is suppression of I kappa B kinase, which is up regulator of nuclear factor kb signalling pathway, and this might be a new therapy approach. Colomo et al. (2003) used immunohistochemistry to divide patients with DLBCL in two groups with similar distribution as we did in our study. According to literature reports patients with GCL 


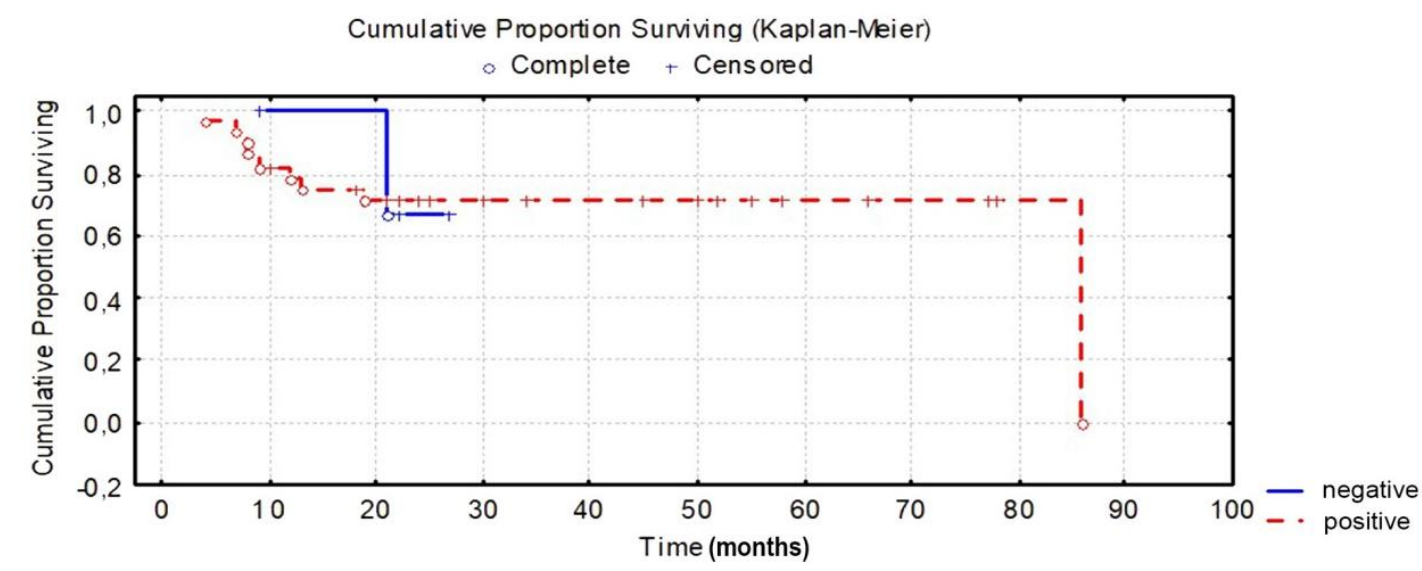

a)

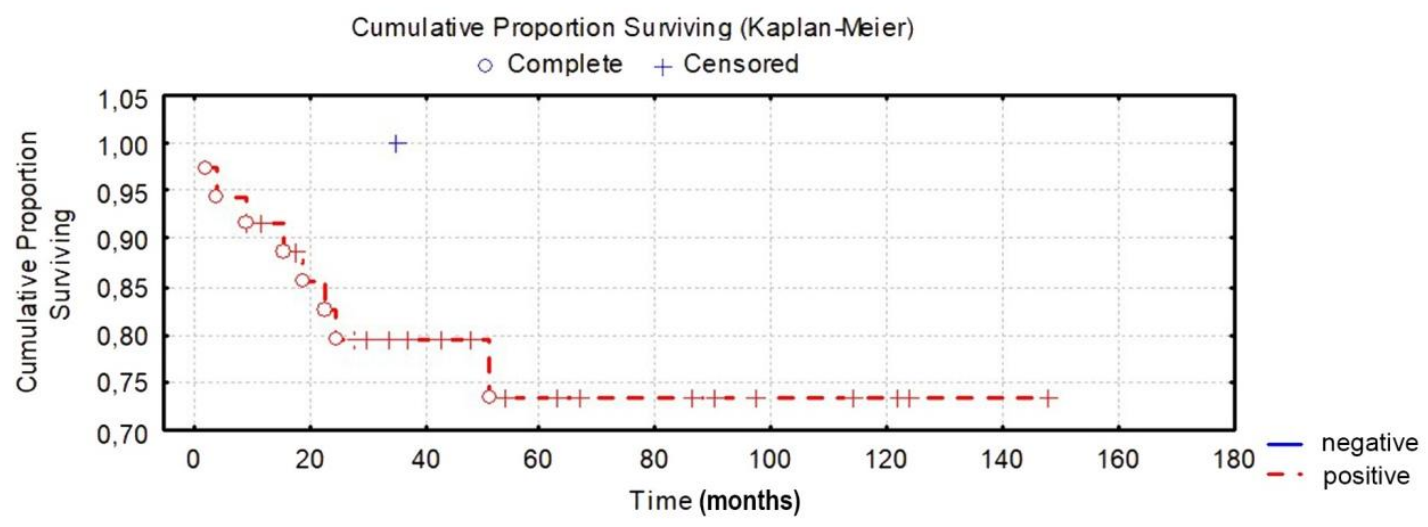

Fig. 4. Overall survival according to BCL6 expression in patients with a) ACL, b) GCL.

have superior overall survival (Colomo et al., 2003; Rosenwald et al., 2006). The prognostic impact of BCL2 protein expression, evaluated in several clinical trials, was significant (Colomo et al., 2003; Hans et al., 2004). It was demonstrated that high BCL2 protein expression found in 59\% of patients was associated with adverse prognostic factors like advanced disease (Colomo et al., 2003), and high IPI score was associated with inferior overall survival (Roh et al., 2020). In our study we confirmed the prognostic importance of BCL2 protein expression, which showed a high predictive capacity in the non-germinal center group. Patients with ACL treated with different modalities of chemoimmunotherapy showed different survival rate more likely due to the cellular origin rather than the effect of therapy. With the introduction of this new prognostic model in everyday practice, we are able to detect a group of patients with inferior survival. This group of patients should be closely monitored and planning for more aggressive therapy or targeted therapy like BCL2 inhibitors or nuclear factor kb signalling pathway inhibitors. Patients with cellular origin from non-germinal center associated with BCL2 expression from diagnosis would be included in a group of patients with early disease evaluation, where after two or four cycles of conventional therapy, they would be evaluated. Those patients with no response would be candidates for early changing the treatment modality in order to avoid the application of therapy that is not associated with the desired effect and application of modern targeted tailoring therapy. Clinical studies are needed to analyze the effects of tailored personalized therapy in patients in this group.

\section{Conclusion}

The development and usage of functional dairy products offers numerous benefits to the consumers and 


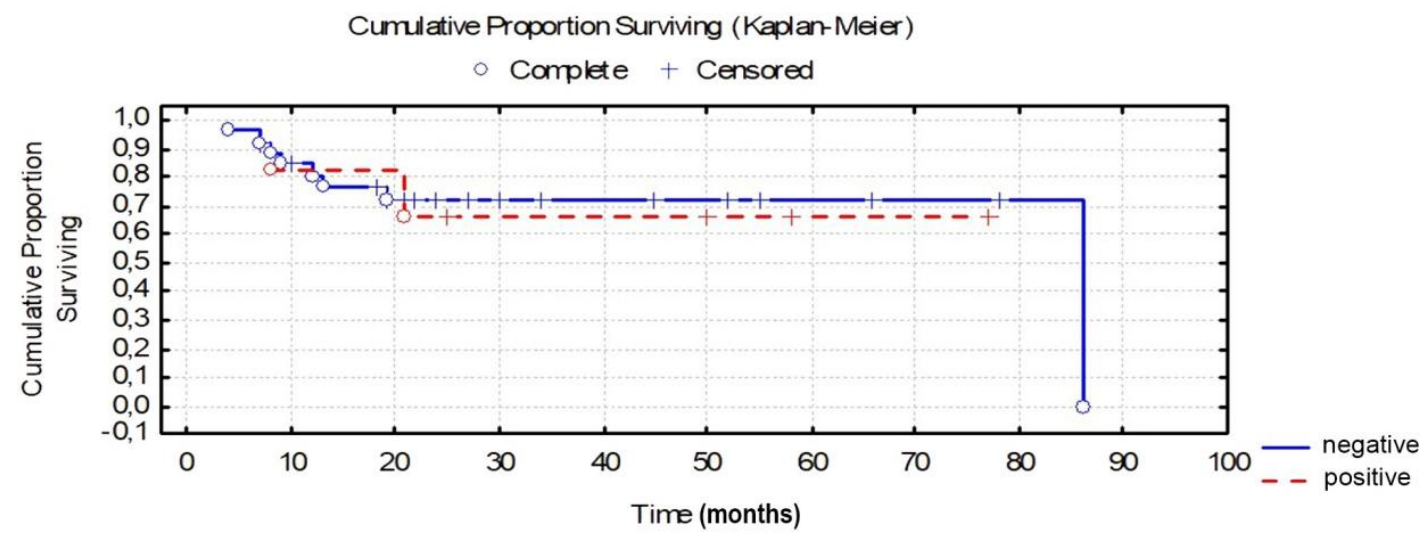

a)

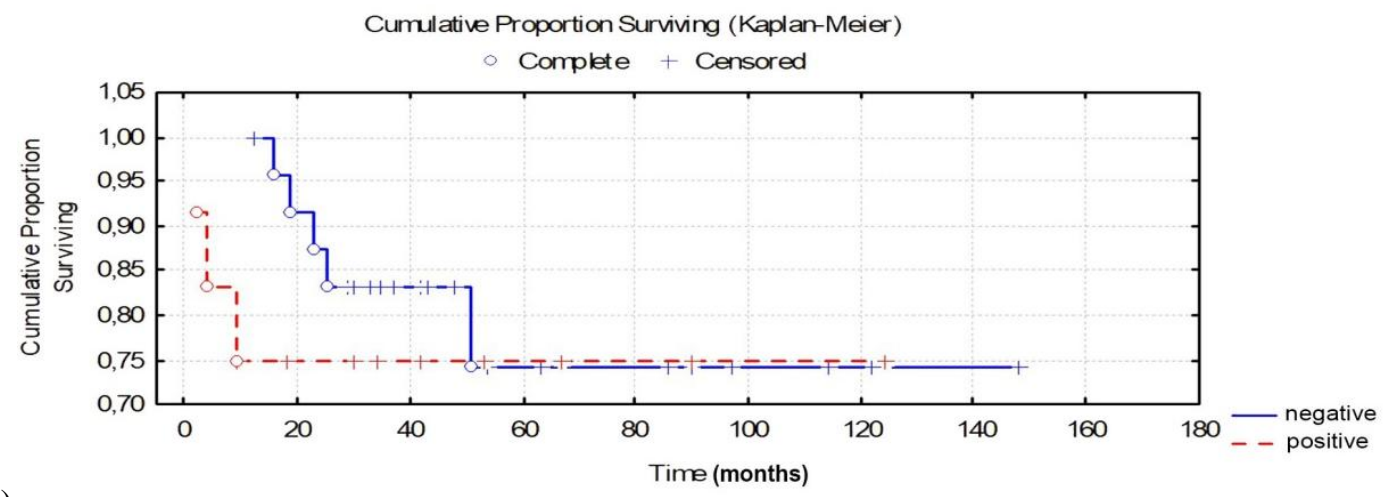

b)

Fig. 5. Overall survival according to MUM1 expression in patients with a) ACL, b) GCL.

represents an important strategy to improve the health and nutritional status of millions of people. These products should be consumed as a part of the healthy diet throughout all life periods especially during childhood and adolescence and in elderly people. In future, their efficacy and health promoting effects must be confirmed in larger clinical studies and collaboration between food producers and scientists must be accomplished. In addition, further understanding of the functional properties of many dairy ingredients would allow food technologists to utilize their potential contribution to product characteristics in order to develop novel functional products. General interest in health and increased consumer awareness as well as perceived self-efficacy has to contribute to shaping the acceptance of functional food products, while the creativity of food technology should further advance the development of food products that can support optimum health.

\section{References}

Armitage, J.O., Gascoyne, R.D., Lunning, M.A., Cavalli, F.,
2017. Non-Hodgkin lymphoma. Lancet 390(10091), 298310. Available at: https://doi.org/10.1016/S01406736(16)32407-2.

Artiga, M.J., Sáez, A.I., Romero, C., Sánchez-Beato, M., Mateo, M.S., Navas, C., Mollejo, M., Piris, M.A., 2002. A short mutational hot spot in the first intron of BCL-6 is associated with increased BCL-6 expression and with longer overall survival in large B-cell lymphomas. Am. J. Pathol. 160(4), 1371-1380. Available at: https://doi.prg/10.1016/S0002-9440(10)62564-3.

Braaten, K.M., Betensky, R.A., De Leval, L., Okada, Y., Hochberg, F.H., Louis, D.N., Harris, N.L., Batchelor, T.T., 2003. BCL-6 Expression Predicts Improved Survival in Patients with Primary Central Nervous System Lymphoma. Clin. Canc. Res. 9(3), 1063-1069. Available at: https://doi.org/10.1158/1078-0432.CCR-21-0066.

Colomo, L., López-Guillermo, A., Perales M., Rives, S., Martínez, A., Bosch, F., Colomer, D., Falini, B., Montserrat, E., Campo, E., 2003. Clinical impact of the differentiation profile assessed by immunophenotyping in patients with diffuse large B-cell lymphoma. Blood 101(1), 78-84. Available at: https://doi.org/10.1182/blood2002-04-1286.

Danial, N.N., Korsmeyer, S.J., 2004. Cell death: critical control points. Cell 116(2), 205-19. Available at: https://doi.org/10.1016/s0092-8674(04)00046-7. 
Dent, A.L., Vasanwala, F.H., Toney, L.M., 2002. Regulation of gene expression by the proto-oncogene BCL-6. Crit. Rev. Oncol. Hematol. 41(1), 1-9. Available at: https://doi.org/10.1016/s1040-8428(01)00164-0.

Falini, B., Fizzotti, M., Pucciarini, A., Bigerna, B., Marafioti, T., Gambacorta, M., Pacini, R., Alunni, C., Natali-Tanci, L., Ugolini, B., Sebastiani, C., Cattoretti, G., Pileri, S., DallaFavera, R., Stein, H., 2013. A monoclonal antibody (MUM1p) detects expression of the MUM1/IRF4 protein in a subset of germinal center B cells, plasma cells, and activated $\mathrm{T}$ cells. Blood 95(6), 2084-9202. PMID: 10706878 .

Hans, C.P., Weisenburger, D.D., Greiner, T.C., Gascoyne, R.D., Delabie, J., Ott, G., Müller-Hermelink, H.K., Campo, E., Braziel, R.M., Jaffe, E.S, Pan, Z., Farinha, P., Smith, L.M., Falini, B., Banham, A.H., Rosenwald, A., Staudt, L.M., Connors, J.M., Armitage, J.O., Chan, W.C., 2004. Confirmation of the molecular classification of diffuse large B-cell lymphoma by immunohistochemistry using a tissue microarray. Blood 103(1), 275-282. Available at: https://doi.org/10.1182/blood-2003-05-1545.

Iqbal, J., Neppalli, V.T., Wright, G., Dave, B.J., Horsman, D.E., Rosenwald, A., Lynch, J., Hans, C.P., Weisenburger, D.D., Greiner, T.C., Gascoyne, R.D., Campo, E., Ott, G., MüllerHermelink, H.K., Delabie, J., Jaffe, E.S., Grogan, T.M., Connors, J.M., Vose, J.M., Armitage, J.O., Staudt, L.M., Chan, W.C., 2006. BCL2 expression is a prognostic marker for the activated B-cell-like type of diffuse large B-cell lymphoma. Journal of Clinical Oncology 24(6), 961-968. Available at: https://doi.org/10.1200/JCO.2005.03.4264.

Muris, J.J., Meijer. C.J., Vos, W., van Krieken, J.H., Jiwa, N.M., Ossenkoppele, G.J., Oudejans, J.J., 2006. Immunohistochemical profiling based on Bcl-2, CD10 and MUM1 expression improves risk stratification in patients with primary nodal diffuse large B cell lymphoma. J. Pathol. 208(5), 714-723. Available at: https://doi.org/10.1002/path.1924.

Ochs, R.C., Bagg, A., 2012. Molecular genetic characterization of lymphoma: Application to cytology diagnosis. Diagn. Cytopathol. 40, 542-555. Available at: https://doi.org/10.1002/dc.22819.

Pasqualucci, L., Migliazza, A., Basso, K., Houldsworth, J., Chaganti, R.S., Dalla-Favera, R., 2003. Mutations of the BCL6 proto-oncogene disrupt its negative autoregulation in diffuse large B-cell lymphoma. Blood 101(8), 2914-2923. Available at: https://doi.org/10.1182/blood-2002-11-3387.

Perona, R., Sánchez-Pérez, I., 2004. Control of oncogenesis and cancer therapy resistance. Br. J. Cancer 90, 573-577. Available at: https://doi.org/10.1038/sj.bjc.6601552.

Rantanen, S., Monni, O., Joensuu, H., Franssila, K., Knuutila, S., 2001. Causes and consequences of BCL2 overexpression in diffuse large B-cell lymphoma. Leuk.
Lymphoma 42(5), 1089-1098. Available at: https://doi.org/10.3109/10428190109097729.

Rosenwald, A., Wright, G., Chan, W.C., Connors, J.M., Campo, E., Fisher, R.I., Gascoyne, R.D., Muller-Hermelink, H.K., Smeland, E.B., Giltnane, J.M., Hurt, E.M., Zhao, H., Averett, L., Yang, L., Wilson, W.H., Jaffe, E.S., Simon, R., Klausner, R.D., Powell, J., Duffey, P.L., Longo, D.L., Greiner, T.C., Weisenburger, D.D., Sanger, W.G., Dave, B.J., Lynch, J.C., Vose, J., Armitage, J.O., Montserrat, E., López-Guillermo, A., Grogan, T.M., Miller, T.P., LeBlanc, M., Ott, G., Kvaloy, S., Delabie, J., Holte, H., Krajci, P., Stokke, T., Staudt, L.M., 2002. Lymphoma/Leukemia Molecular Profiling Project. The use of molecular profiling to predict survival after chemotherapy for diffuse large-Bcell lymphoma. N Engl. J. Med. 346(25), 1937-1947. Available at: https://doi.org/10.1056/NEJMoa012914.

Roh, J., Cho, H., Yoon, D.H., Hong, J.Y., Lee, A.N., Eom, H.S., Lee, H., Park, W.S., Han, J.H., Jeong, S.H., Park, J.S., Pak, H.K., Kim, S.W., Kim, S.Y., Suh, C., Huh, J., Park, C.S., 2020. Quantitative analysis of tumor-specific BCL2 expression in DLBCL: refinement of prognostic relevance of BCL2. Sci. Rep. 10(1), 10680. Available at: https://doi.org/10.1038/s41598-020-67738-4.

Swerdlow, S.H., Campo, E., Pileri, S.A., Harris, N.L., Stein, H., Siebert, R., Advani, R., Ghielmini, M., Salles, G.A., Zelenetz, A.D., Jaffe, E.S., 2016. The 2016 revision of the World Health Organization classification of lymphoid neoplasms. Blood 127(20), 2375-2390. Available at: https://doi.org/10.1182/blood-2016-01-643569.

Swerdlow, S.H., Campo, E., Harris, N.L., Jaffe, E.S., Pileri, S.A., Stein, H., Thiele, J., 2017. WHO Classification of Tumours of Haematopoietic and Lymphoid Tissues, Volume 2 (rev. ed. 4). Lyon, France, International Agency for Research on Cancer. Available at:

https://publications.iarc.fr/Book-And-Report-Series/WhoClassification-Of-Tumours/WHO-Classification-OfTumours-Of-Haematopoietic-And-Lymphoid-Tissues2017.

Wright, G., Tan, B., Rosenwald, A., Hurt, E.H., Wiestner, A., Staudt, L.M., 2003. A gene expression-based method to diagnose clinically distinct subgroups of diffuse large B cell lymphoma. Proc. Natl. Acad. Sci. USA 100(17), 99919996. Available at: https://doi.org/10.1073/pnas.1732008100.

Zinzani, P.L., Dirnhofer, S., Sabattini, E., Alinari, L., Piccaluga, P.P., Stefoni, V., Tani, M., Musuraca, G., Marchi, E., Falini, B., Baccarani, M., Pileri, S.A., 2005. Identification of outcome predictors in diffuse large B-cell lymphoma. Immunohistochemical profiling of homogeneously treated de novo tumors with nodal presentation on tissue microarrays. Haematologica 90(3):341-347. PMID: 15749666. 
Резиме

\title{
Прогностичко влијание на имунофенотипот кај дифузно крупноклеточниот Б лимфом - искуство на еден центар
}

\author{
Сања Трајкова ${ }^{1}$, Светлана Крстевска Балканов ${ }^{1}$, Гордана Петрушевска ${ }^{2}$, \\ Лидија Чевреска ${ }^{1}$, Александра Пивкова Вељановска ${ }^{1}$, \\ Марија Попова-Лабачевска ${ }^{1}$, Невенка Ридова ${ }^{1}$, Симона Стојановска ${ }^{1}$, \\ Ирина Пановска Ставридис ${ }^{1}$
}

\author{
${ }^{1}$ Универзитетска клиника за хематологија, Медицински факултет, \\ Универзитет „Св. Кирил и Методиј“, Мајка Тереза 17, \\ 1000 Скопје, Република Северна Македонија \\ ${ }^{2}$ Институт за патологија, Медииински факултет, \\ Универзитет „Св. Кирил и Методиј “, 50 Дивизија 6, \\ 1000 Скопје, Република Северна Македонија
}

Клучни зборови: ДККБЛ, тримаркерски модел, имунохистохемија, БЦЛ2

Концептот генериран од профилот на биолошко изразување ги подели пациентите со дифузен крупноклеточен Б лимфом (ДККБЛ) на два поттипа, презентиран во неодамнешните изданија на СЗО класификацијата, и истиот претставува прогностичка алатка. Цел на студијата е воведување на нов модел со три маркери за имунохистохемиска, прогностичка супкласификација на пациенти со ДККБЛ.

Нашата ретроспективна студија опфати 200 возрасни пациенти со ДККБЛ дијагностицирани и третирани во периодот од јануари 2013 до јануари 2021 година. Сите беа третирани со хемоимунотерапија со R +/- CHOP протоколот, со средно следење на пациентите од 48 месеци. Имунохистохемиски ги анализиравме примероците од биопсија со маркерот на герминалниот (БЦЛ6), постгерминалниот центар (МУМ1) и маркерот за апоптоза (БЦЛ2).

Користејќи имунохистохемиски тримаркерски модел кој се состоеше од БЦЛ2, БЦЛ6, МУМ1, ние ги поделивме пациентите со ДККБЛ на 2 подгрупи: герминален центар (ГЦЛ) и активирачки центар лимфом (АЦЛ). Пациентите со ГЦЛ и АЦЛ имаа споредливи резултати во однос на возраста, полот и сите други веќе утврдени прогностички параметри. Пациентите со ГЦЛ имаа вкупно преживување од 140 месеци, а пациентите со АЦЛ имаа вкупно преживување од 88 месеци. Пациентите со АЦЛ со експресија на БЦЛ2 имаа пократко преживување во споредба со пациентите со АЦЛ без експресија на БЦЛ2; разликата во преживувањето беше статистички значајна за $p=0,01914$.

Студијата го воведе новиот модел со три маркери за имунохистохемиска супкласификација на пациенти со ДККБЛ третирани со имунохемотерапија. Маркерот на апоптоза БЦЛ2 е силен предиктор за преживување. Во оваа студија ја потврдивме прогностичката важност на експресијата на БЦЛ2 протеинот, што го покажа предиктивен капацитет во АЦЛ. 